\title{
FISCAL IMBALANCE AND FISCAL RISKS MANAGEMENT ON THE REGIONAL LEVEL
}

\section{Petra Dvořáková}

Department of Public Economics, Faculty of Economics and Administration, Masaryk University, Lipová 41a, 60200 Brno, Czech Republic, email: dvorako1 @econ.muni.cz

\begin{abstract}
The aim of the paper was to evaluate usage of the fiscal instruments (mainly liabilities and fiscal risks management) in present practice of Czech regions. The current practice of fiscal instruments was explored particularly by the means of structured interviews in which representatives of all Czech regions participated. The survey showed different attitudes to debt/liabilities management exercised on the Czech regional level. An active debt management, as defined by the theory, has not been encountered in any of the Czech regions (except for the capital of Prague), although their representatives are convinced otherwise. Risk maps or risk matrixes are not usually created either but the risks connected with the regional budgets are monitored (especially currency risks and interest rate risks) and solved if necessary.
\end{abstract}

Key words: Fiscal Imbalance, Indebtedness, Fiscal Risks, Risks Map, Czech Regions

JEL Classification: H6, H7

DOI: $10.2478 / \mathrm{v} 10135-011-0011-1$ 


\title{
FISCAL IMBALANCE AND FISCAL RISKS MANAGEMENT ON THE REGIONAL LEVEL ${ }^{1}$
}

\section{Petra Dvořákováa}

\section{Introduction}

Regions as higher territorial self-governing units were established by constitutional act no. 347/1997 Coll., and thus a new level of public administration and of public budgets, too, was created. The establishment of regions is related to the year 2001, when the first stage of public administration reform was implemented. For this purpose, a legislative framework was provided in 2000 by accepting Act no. 129/2000 Coll., on Regions (regional establishment). In the autumn of the same year, the first public elections of regional representatives were held and brought the compositions of the first bodies of representatives and also other administrative bodies of the regions elected by them. Moreover, regional authorities were founded and started to perform the tasks entrusted to them by particular regulations. Regions started working practically in 2001 when they took their significant position in the public budget system.

\begin{abstract}
Aim and methods
The aim of the paper is to evaluate current usage of fiscal instruments (mainly fiscal imbalance and fiscal risks management) on the level of the Czech regions. First, we theoretically introduce the theory of fiscal imbalance and the possible problems associated with it by taking into account standard theoretical economic literature. Subsequently we shall explore the instrument which could be used to control fiscal risks at the regional level - a risk map. The paper continues with mapping the regional economic developments since establishment of the regions up till now, whilst their annual economic results and the related development of indebtedness are emphasized. In the last section, we are dealing with the indebtedness of regions from the perspective of their representatives' experience. As a conclusion, we present a summary and recommendations.
\end{abstract}

The paper does not discuss indebtedness of regions or reasons of indebtedness regulation as it is the topic of previous papers published by the author. ${ }^{3}$ We assume that certain regulation by state is better then no rule at all, as it is apparent in foreign experience. Considering indebtedness regulation and related rules we prefer ex-ante ones to ex-post.

The current practice of fiscal instruments used by Czech regions was explored by means of structured interviews which were the main method of data collection. Selected representatives of all Czech regional authorities, namely the executives of the Economic

\footnotetext{
1 The contribution was made thanks to the project of the Czech Science Foundation No. 402/08/1158.

2 Department of Public Economics, Faculty of Economics and Administration, Masaryk University, Lipová 41a, 60200 Brno, Czech Republic. Email: dvorako1@econ.muni.cz.

${ }^{3}$ See for example Dvořáková (2007), Dvořáková (2010), Dvořáková (2009).
} 
Departments and Departments of Finance of the Regional Authorities and their associates and delegates, were addressed as respondents. The interviews were conducted by the research team of the Department of Public Economy, Faculty of Economy and Administration, Masaryk University, from June to September 2010.

The Automated Budget Information System of the Czech Ministry of Finance (ARIS) was the main source of the regional authorities' data concerning their budgetary aspects (as summarized in the tables below). This information system collects data from accounting and reporting of individual components of public budgets, including regions. Budgetary documents of regions and state budgets were also used to describe financial situation of the regions, their economic results and indebtedness.

\section{Fiscal Imbalance at the Regional Level}

By a fiscal imbalance we generally mean any discrepancy between budgetary revenues and budgetary expenditures within a certain period. If we take into consideration one budget year only, we can obtain three different economic results, or three results of the relationship between budgetary revenues and budgetary expenditures. Ideally, these two quantities will be equal; in this case there is a balance. In the other two cases, there is a short-term fiscal imbalance - a deficit (expenditures are higher than revenues), or a surplus (revenues are higher than expenditures). In both cases, it is necessary to tackle the imbalance.

If such a result of budget has not been planned and is found out during a budget year, it is possible to perform a budget correction, e.g. cross out some expenditure or increase the revenues. If the balance in question has been planned, the situation is simpler, especially in case of a surplus; a surplus can be placed in reserves (e.g. a bank account, term deposits), or used for the payment of a part of liabilities. A deficit brings about the need to finance the expenditures not covered by the budgetary revenues from other sources, e.g. to involve the reserves, to apply for a loan, issue bonds, sell property, etc.

What can be the consequences of a short-term fiscal imbalance, or rather deficit (the theory associates no negative consequences with a surplus)? From a short-term point of view, this does not necessarily constitute any serious trouble, unless the matter becomes chronic. Thanks to a short-term deficit, there can be an increase in a budget constraint which can lead to higher investments or an automatic response to the decline phase of the economic cycle. However, the trouble arises if deficits appear annually and accumulate into a growing debt. Then also interests rise and these again burden the budget as expenses.

This brings us to a long-term fiscal imbalance which means a discrepancy between budgetary revenues and budgetary expenditures in the long-term perspective. Put simply, this is accumulated deficits from previous years which thus create a debt. However, a more accurate definition says that this is a sum of budget liabilities due to other economic entities. These entities can be banks, households, companies, but also government institutions, if they provided means to the budget in question (e.g. in the form of a loan, a returnable financial support, etc.). Naturally, for these loaned means some price has to be paid - an interest. Generally, we can say that the volume of interests grows with a growing debt. 
Many risks are associated with the debt portfolio - the basic ones are refinancing risk, interest rate risk, currency risk, liquidity risks and the counterparty risk (Medved' et al. 2005 , p. 350). Therefore, it is recommendable to diversify the debt portfolio both with respect to financial instruments (loans, securities) and with respect to their due periods (short-term, long-term instruments) or creditors. The activities connected with the debt portfolio are together referred to as debt management. This concerns an active influence on the amount and the structure of the debt aimed at the optimization of the amount of the debt and the minimization of the related expenses and risks. The choice between the amount of expenses and risks is one of the most important decisions to make concerning debts, as these two are in an antagonistic relationship.

How does the current legislation on the economic activities of regions respond to the theory of fiscal imbalance? Act No. 250/2000 Coll., on Budgetary Rules for Local Governments which generally regulates the creation, position, the content and functions of budgets of territorial self-governing units and specifies the rules for the management of financial means of territorial self-governing units is one of the most significant acts related to the management of regional budgets; it also deals with the establishment of legal entities of territorial self-governing units ( $\$ 1$ art. 1 of Act No. 250/2000 Coll.). It establishes the budget and the budgetary outlook as the basic tools of financial management ( $\$ 2$ art. 1 of the Act No. 250/2000 Coll.). A budget year is equal to a calendar year ( $\$ 4$ art. 2 of the Act No. 250/2000 Coll.).

The act concerning the balance of regional budgets says that they should be drawn up as balanced. Besides this, a surplus budget is possible if some of the incomes are planned to be used in the following years, or if they are determined to settle debts from previous years. A surplus can also be deposited in the region's money funds. Moreover, there can also be a deficit budget if the deficit is possible to cover by financial means from past years or by a loan secured by contract, credit, returnable financial support, or yield on sale of communal bonds ( $\$ 4$ art. $4-6$ of the Act No. 250/2000 Coll.). Thus the act directly stipulates the options of covering a deficit.

In case of a temporary discrepancy between budgetary revenues and budgetary expenditures, the act stipulates the option to accept a returnable financial support from the state budget or a budget of another region. An important fact for such a region is that the returnable financial support is interest free. However, if it is returned after due date, this is considered retention of financial means ( $\$ 8$ art. 5 of the Act No. 250/2000 Coll.).

If the region finds out during the year that the budgetary revenues or expenditures do not develop in agreement with their expectations and there is the threat of a deficit, it can adjust its budget by taking budgetary measures. A budgetary measure can be of three forms. Either it is a transfer of budget means within revenues and expenditures so that their approved volume does not change. Or, new, non-budgeted revenues are used to settle non-budgeted expenditures, which increases the total volume of the budget. The last option is binding of budgetary expenditures if there is the danger they would not be covered by budgetary revenues, which means the decrease in the budget volume ( $\S 16$ art. $1-3$ of Act No. 250/2000 Coll.).

The resulting balance of the regional budget is published in the closing financial statement of the region. The closing financial statement contains the information on how the budget of incomes and expenses was met in its full stipulated structure, 
information about managing the property and other financial operations, including the formation and use of funds ( $\$ 17$ art. 2 of Act No. 250/2000 Coll.).

The region's liabilities are generally regulated by Act No. 129/2000 Coll., on Regions, not budgetary rules. The mentioned act in this context stipulates that the region is represented in legal relationships by its own name and bears the responsibilities or liabilities following from its relationships ( $\$ 1$ art. 2 of Act No. 129/2000 Coll.). An acceptance of a loan or an issuance of communal bonds is a kind of such legal relationship. The body responsible for taking over of the liabilities on behalf of the region is its representatives. They are to make decisions about agreements on the acceptance and provision of a loan, credit, acceptance of a guarantee liability or agreement with a liability ( $\$ 36$ letter i) of Act No. 129/2000 Coll.).

To prevent uncontrollable growth of indebtedness of a region outside the budget, the act prohibits regions to guarantee for liabilities of natural persons or legal entities, except for cases listed ( $\$ 17$ art. 3 of Act No. 129/2000 Coll.). On the other hand, the state does not guarantee for the economy and the liabilities of a region unless it takes the liability over based on a contract ( $\$ 17$ art. 5 of Act No. 129/2000 Coll.). This stipulation protects the state against automatic taking over of bad decisions of regions concerning liabilities. It is necessary to note that a similar stipulation is valid for municipalities; however, the state has taken over liabilities of municipalities which had troubles several times (for example the case of Rokytnice nad Jizerou). Analogically, we can assume that also in case a region had serious troubles, the state would solve the situation actively. Such an assumption creates space for potential "moral hazard" to appear in the field of regional indebtedness.

Based on the above mentioned, we can ask the question whether the state controls or regulates the indebtedness of regions in some way. The answer is currently a negative one; at the moment, the state does not regulate the amounts of liabilities of regions. It has not always been like this. In 2004 - 2008 government decree No. 346, on the regulation of the indebtedness of municipalities and regions by means of the debt service indicator was effective. The resolution allowed the Ministry of Finance to calculate the indicator of debt service annually for all municipalities and regions of the Czech Republic and if the limit (30\%) was exceeded, the municipality or the region had to explain the situation. At the same time, there was a threat that if the municipality or the region exceeded the limit of the debt service indicator in the long term and without any satisfactory explanation, the providers of subsidies from the state budget and state funds could take this into consideration when deciding about a provision of a subsidy (MoF, 2005c). However, this option was rather hypothetical and was not often used in the practice.

If we go deeper into the past, measures aimed at the reduction of the indebtedness of regions were taken even before 2004. They had a form of amendments to the act on regions. The first amendment was implemented by act no. 450/2001 Coll. and it added the following stipulations into the act on regions: a conclusion of an agreement on the acceptance of a credit or loan by a region from abroad had to be approved by the government; also issues of communal bonds had to be approved by the government; a region could not accept a loan if its debt service had exceeded $15 \%$ of its own budget from the last year; a region could not guarantee for liabilities of natural persons or legal 
entities with its property unless the region was their founder; and the last change dwelled in the stipulation that the state does not guarantee for the economy and liabilities of a region unless it takes them over based on an agreement. It was then proved in the practice that these measures were not really clear and they brought serious problems. Therefore, the next amendment to the act on regions by act no. 231/2002 Coll. cancelled most of the measures mentioned above. Only the measures regarding guarantees (state for a region, region for legal entities and natural persons) remained.

By accepting the CR government decree of November 12, 2008, No. 1395, on monitoring of the economic activities of municipalities and cancelling the government decree of April 14, 2004, No. 346, on the regulation of indebtedness of municipalities and regions by the means of the debt service indicator, the regions, or rather their indebtedness, ceased to be monitored by the Ministry of Finance. As the title of the "new" government decree shows, the monitoring is further applied to municipalities only - every year the Ministry of Finance calculates a set of informative and monitoring indicators (see Table 1) and evaluates the results.

Table 1: System of Informative and Monitoring Indicators (SIMI)

\begin{tabular}{|l|}
\hline A. Informative Indicators \\
\hline 1) Number of inhabitants \\
\hline 2) Revenues in total (after consolidation) \\
\hline 3) Interests \\
\hline 4) Paid installments of bonds and loaned means \\
\hline 5) Debt service in total \\
\hline 6) Debt service indicator (in \%) \\
\hline 7) Assets total \\
\hline 8) Loaned sources \\
\hline 9) Balance on bank accounts in total \\
\hline 10) Loans and communal bonds \\
\hline 11) Accepted returnable financial supports and other debts \\
\hline 12) Indebtedness total \\
\hline 14) Share of indebtedness in loaned sources (v \%) \\
\hline 15) Loaned sources per an inhabitant \\
\hline 16) Current assets \\
\hline 17) Short-term liabilities \\
\hline B. Monitoring Indicators \\
\hline 13) Share of loaned sources in total assets (v \%) \\
\hline 18) Total (current) liquidity \\
\hline
\end{tabular}
Source: $M o F(2005 b)$.

In the entire set, the two monitoring indicators are the most important. Municipalities will be, similarly as the previous instrument of debt service, addressed by the Ministry of Finance and asked to provide an explanation if the indicator of total liquidity at the end of current year is within interval $\langle 0 ; 1\rangle$, and at the same time the share of loaned sources in total asset is higher than $25 \%$ (MoF, 2005b).

Although this set of informative and monitoring indicators is not obligatory for regions and is not monitored by the Ministry of Finance, the interviews showed that some 
regions calculate and evaluate these indicators for their own purposes. These are standard indicators of a financial health of an entity and are naturally appropriate if the region is aware of its financial situation. That is why we prepared the table in the Appendix 1, which shows the data as of 31/12/2009 in the structure of the informative and monitoring indicators for all regions of the Czech Republic.

\section{Fiscal Risks Management at the Regional Level}

Regions gradually started to implement modern methods for the control of their budgets, either in relation to the entrance of the Czech Republic in the EU or the reform of public budgets. These methods should help to bring better quality into activities of regions, and to make expenditures of public means more effective. Fiscal risk management represents one of these methods. In compliance with the act on financial control in public administration, the regions of the Czech Republic need to have a system which will not only monitor risks and prepare regions for them but also manage them. Specifically, one of the main aims of the mentioned act is "to ensure the protection of public means against risks, discrepancies or other deficiencies caused mainly by breach of legal regulations, uneconomical, purposeless and inefficient use of public means or by criminal activities." ( $\$ 4$ art. 1 of the Act No. 320/2001 Coll.).

Consistent monitoring and evaluation of risks can prevent negative impacts on a regional budget. The identification of causes or the origination of fiscal risks is within the competence of regional managers. Their knowledge and personal experience are irreplaceable. That is another reason why the current practice of fiscal risk management in the regions of the Czech Republic was explored by means of interviews. Several representatives of the regional authority were interviewed in each region. In dependence on their knowledge of the specific situation of a region and their experience in risk management, risks themselves and also their possible consequences were evaluated using a five-point scale. For the purposes of the analysis, each of the evaluated risks and consequences was assigned a value from zero to five decimal points could also be used. ${ }^{4}$

The scale of risks and consequences is presented in Table 2. Classification of a risk according to its consequence as 1 does not mean that the risk is automatically classified as 1 from the perspective if its probability; a risk can gain any value of the scale.

\footnotetext{
${ }^{4}$ Methodical instruction of the Ministry of Finances of the Czech Republic proposes a five-point scale without decimal points (see MoF, Audit Department - Central Harmonisation Unit (2004, April)).
} 
Table 2: Consequences/evaluation of risks

\begin{tabular}{|c|c|c|c|}
\hline To & $\begin{array}{l}\text { Consequences } \\
\text { (C) }\end{array}$ & To & Probability; evaluation of risk; response $(\mathrm{P})$ \\
\hline 1 & None & 1 & Nearly impossible; borders on a statistical error; record only \\
\hline 2 & Negligible & 2 & $\begin{array}{l}\text { Common risk; occurrence of a risk is possible but not } \\
\text { necessary; no response }\end{array}$ \\
\hline 3 & Acceptable & 3 & Acceptable; the risk occurs sporadically; prevention \\
\hline 4 & Undesirable & 4 & $\begin{array}{c}\text { Acceptable in case of high expenses on the risk removal; } \\
\text { probable occurrence; immediate response }\end{array}$ \\
\hline 5 & Unacceptable & 5 & Unacceptable; an expected risk; fundamental reassessment \\
\hline
\end{tabular}

Source: ŠVEC, P. Řízení fiskálních rizik (na úrovni krajských rozpočtio ČR). Brno, 2009, p. 41.

Further, risks were classified into three main groups according to their significance. The significance of a risk (S) was ascertained based on the relationship between consequences $(\mathrm{C})$ and probability $(\mathrm{P})$ by the means of the following equation $\mathrm{S}=\mathrm{P} * \mathrm{C}$ (MoF, Audit Department - Central Harmonisation Unit (2004, April)). Based on the calculated values, the risks can be divided into common ones (operational), serious ones, and critical ones. The boundaries between particular groups of risks were established as follows: $S=2$ as the boundary between common and serious risks, $R=8$ as the boundary between serious and critical risks.

The survey did not deal with general financial risks such as robbery, fraud or carelessness. These risks are monitored and secured in all examined regions very well. Therefore, the survey focused on fiscal and budget risks which are associated with the budgets of regions, like liquidity risk, refinancing risk, interest rate risk, etc. The risks connected with regional budgets are specified in the result table (Table 3) for the South Moravian Region as risks R1 - R16. The South Moravian Region was randomly chosen for the demonstration of risk assessment on a regional level. The probability values and the values for the consequences were established by the research team on the basis of interviews, their own expert knowledge and the development of the South Moravian budget in the past. The results could differ from estimates of other entities or persons. 
Table 3: Risks Evaluation for the South Moravian Region

\begin{tabular}{|c|c|c|c|c|}
\hline \multicolumn{2}{|r|}{ Description of the activity and operation } & $\mathrm{C}$ & $\mathrm{P}$ & $\mathrm{S}$ \\
\hline \multicolumn{5}{|c|}{ Budget risks } \\
\hline R1 & Unrealistic budget incomes - incomes over-evaluated & 3.2 & 3.1 & 9.9 \\
\hline R2 & Budgetary expenses under-evaluated & 3.0 & 2.7 & 8.1 \\
\hline R3 & Approval of budgetary measures without sources secured & 3.9 & 2.7 & 10.5 \\
\hline R4 & Meeting the budget structure & 1.1 & 0.6 & 0.7 \\
\hline R5 & Financing of a budget deficit - whether realistic & 3.2 & 2.2 & 7.0 \\
\hline R6 & Debts service of the region & 3.8 & 3.1 & 11.8 \\
\hline \multicolumn{5}{|c|}{ Liquidity risks } \\
\hline R7 & $\begin{array}{l}\text { Insufficient cover of liabilities by immediate assets - } \\
\text { insufficient liquidity }\end{array}$ & 1.6 & 2.6 & 4.2 \\
\hline R8 & Negative cash-flow & 1.0 & 1.4 & 1.4 \\
\hline \multicolumn{5}{|c|}{ Refinancing risks } \\
\hline R9 & $\begin{array}{l}\text { Inability to secure sufficient reserves for the financing } \\
\text { of the first debt }\end{array}$ & 3.4 & 3.4 & 11.6 \\
\hline $\mathrm{R} 10$ & Refinancing of the debt & 2.8 & 3.0 & 8.4 \\
\hline \multicolumn{5}{|c|}{ Currency risk } \\
\hline $\mathrm{R} 11$ & $\begin{array}{l}\text { Change of currency rate of the returnable sources in } \\
\text { foreign currencies }\end{array}$ & 1.0 & 1.1 & 1.1 \\
\hline \multicolumn{5}{|c|}{ Interest rate risk } \\
\hline $\mathrm{R} 12$ & $\begin{array}{l}\text { Change of interest rates connected with the movement } \\
\text { of e.g. repo rate }\end{array}$ & 2.6 & 2.7 & 7.0 \\
\hline \multicolumn{5}{|c|}{ Political risks (decisions of regional authorities) } \\
\hline R13 & $\begin{array}{l}\text { Decision making of self-government authorities without } \\
\text { complete information }\end{array}$ & 3.2 & 3.8 & 12.2 \\
\hline $\mathrm{R} 14$ & $\begin{array}{l}\text { Decisions of regional authorities contrary to } \\
\text { recommendations of risk analysis }\end{array}$ & 4.3 & 3.9 & 16.8 \\
\hline $\mathrm{R} 15$ & Realistic approved expenses with respect to sources & 3.1 & 3.1 & 9.6 \\
\hline \multicolumn{5}{|c|}{ Liability risk } \\
\hline $\mathrm{R} 16$ & Liabilities after the due date & 1.6 & 1.2 & 1.9 \\
\hline
\end{tabular}

The table shows that critical risks include risks connected with the decision-making processes of the regional authorities, and some budget and refinancing risks. To visualize risk factors graphically a risk map is used. The following diagram (Figure 1) shows the location of risks in the map based on the significance of their impact and the probability that they will occur. We can identify the three types of risks mentioned above according to their seriousness - low, medium and high risk. 
Figure 1: Risks Map

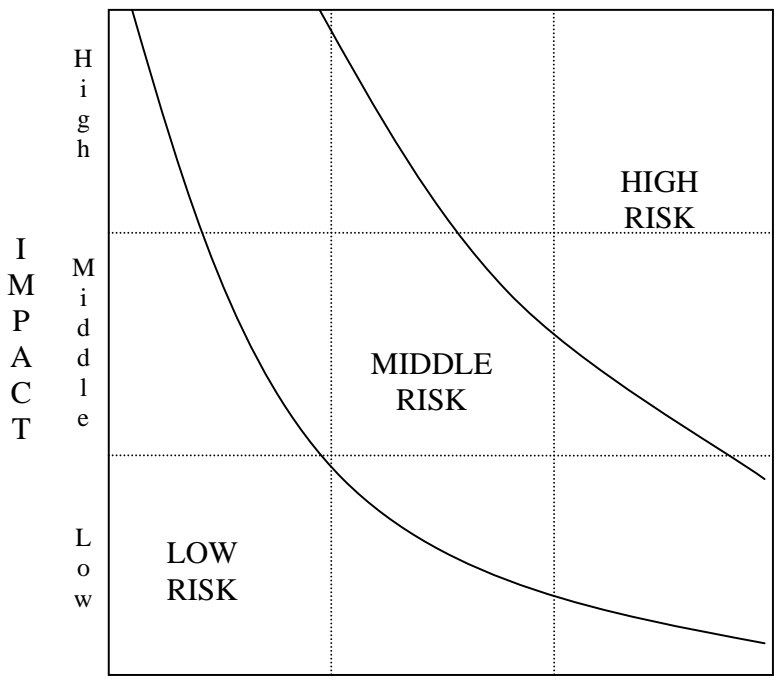

PROBABILITY

Source: The author based on SEVERA, J. (28. 5. 2004)

Figure 2 shows the results for the South Moravian region based on the values calculated in Table 4. We can see that most risks are found in the area of high risk, the numbers of risks in the medium and low risk areas are balanced. We have to state that the evaluation of risks was conducted in the period of a subsiding economic recession, which significantly influenced the revenue and the expenditure sides of the South Moravian budget. Besides the necessary cuts in expenditures caused by decrease in tax revenues, the representatives approved a financial support for local entrepreneurs. For these reasons, the structure of revenues and expenditures of the budget changed substantially in comparison with the approved budget, which was reflected in the increase in considered risks. 
Figure 2: Risks Map for the South Moravian Region

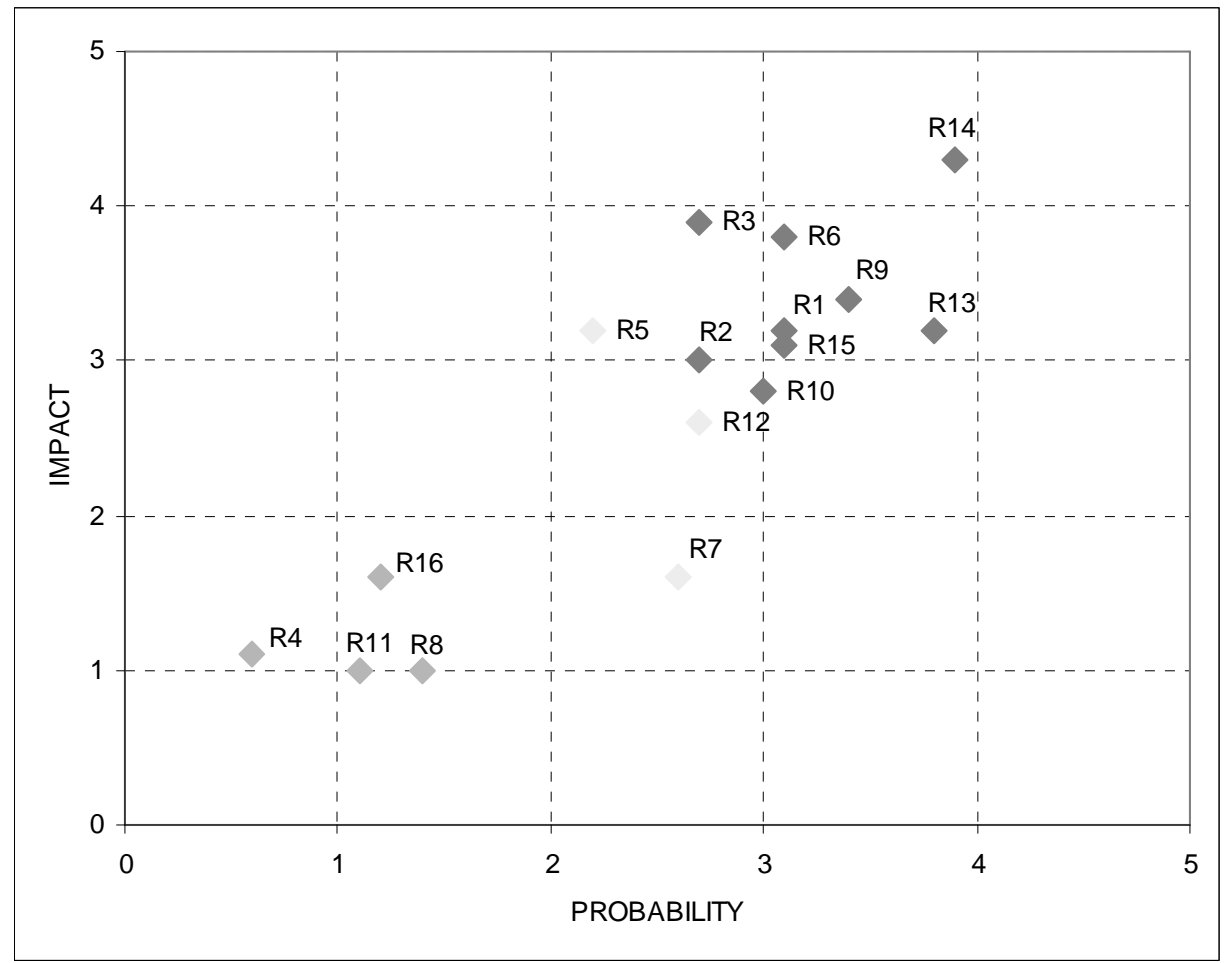

Source: The author based on Table 4.

Similar risk maps could be constructed for all regions of the Czech Republic. The conducted interviews proved that this tool is not used widely. The regions more or less monitor the risks associated with the regional budget; however, we have hardly seen an evaluation of risks by means of the above mentioned method or a risk map in the regions (see results of interviews below). A possible explanation could be that regions have operated in a relatively stable economic environment, their budgets have not been exposed to larger stresses and liabilities have not reached alarming levels so far. At the same time, regions have, or rather had until 2009, considerable reserves deposited in bank accounts, and these could be used to solve potential narrow points in the budget. It is possible that risk management was not a primary interest for these reasons. Nevertheless, in connection with the subsiding economic recession and the running out reserves, fiscal risk management should be recommended to regions as a standard tool for the regional budget management.

\section{Development of Regional Indebtedness}

At the beginning of this part, we have to note that the following text on the development of regional economic activities will mainly concern thirteen regions of the Czech Republic without the capital of Prague. The reason is that we base our research on the data from the Ministry of Finance (MoF), in which the economic data of Prague is 
included in the section of municipalities, not regions. That is why the tables illustrating the development of regional balances and their indebtedness have to be interpreted with the aforementioned limitation. Table 4 shows the development of the structure of revenues and expenditures of regions and also the final balances of their economic results. The most important factors which have affected their development are revealed in the text that follows.

\section{Table 4: Development of Economic Balances of Regional Budgets}

\begin{tabular}{|l|r|r|r|r|r|r|r|r|r|r|}
\hline In bil. CZK & 2001 & 2002 & 2003 & 2004 & 2005 & 2006 & 2007 & 2008 & 2009 & 2010 \\
\hline I. Tax revenues & 0.00 & 10.17 & 11.40 & 12.58 & 39.61 & 42.27 & 46.08 & 49.82 & 43.78 & 45.10 \\
\hline II. Non-tax revenues & 0.07 & 0.72 & 1.42 & 3.18 & 2.81 & 2.94 & 3.48 & 3.87 & 3.96 & 4.90 \\
\hline III. Capital revenues & 0.01 & 0.04 & 0.24 & 0.34 & 0.36 & 0.36 & 0.83 & 0.62 & 0.41 & 1.11 \\
\hline Own sources & 0.08 & 10.93 & 13.06 & 16.10 & 42.78 & 45.57 & 50.39 & 54.30 & 48.20 & 51.11 \\
\hline IV. Grants & 14.44 & 26.70 & 82.76 & 84.61 & 70.69 & 76.56 & 75.02 & 77.42 & 88.73 & 89.51 \\
\hline non-investment grants & 12.02 & 24.26 & 75.12 & 76.14 & 69.52 & 73.01 & 70.17 & 73.25 & 80.25 & n.a. \\
\hline investment grants & 1.21 & 2.41 & 7.38 & 8.38 & 2.04 & 3.55 & 4.85 & 3.44 & 2.58 & n.a. \\
\hline Total revenues & 14.52 & 37.63 & 95.82 & 100.71 & 113.47 & 122.13 & 125.41 & 131.73 & 136.87 & 140.62 \\
\hline V. Current expenditures & 13.22 & 32.07 & 84.96 & 88.39 & 100.59 & 108.49 & 107.68 & 112.55 & 120.91 & 118.68 \\
\hline VI. Capital expenditures & 1.22 & 3.73 & 9.37 & 11.50 & 11.98 & 15.91 & 16.62 & 20.49 & 23.73 & 20.04 \\
\hline Total expenditures & 14.44 & 35.80 & 94.33 & 99.89 & 112.57 & 124.40 & 124.30 & 133.04 & 144.64 & 138.73 \\
\hline Balance & $\mathbf{0 . 0 7}$ & $\mathbf{1 . 8 2}$ & $\mathbf{1 . 4 9}$ & $\mathbf{0 . 8 3}$ & $\mathbf{0 . 9 0}$ & $\mathbf{- 2 . 2 7}$ & $\mathbf{1 . 1 0}$ & $\mathbf{- 1 . 3 1}$ & $\mathbf{- 7 . 7 7}$ & $\mathbf{1 . 8 9}$ \\
\hline
\end{tabular}

Source: MoF (2010). State Financial Statement for the years 2001-2010.

Regions started their economic activities with their budgets in 2001, when the first stage of the public administration reform was implemented. In January 2001, state property started to be transferred to them (in compliance with Act no. 157/2000 Coll.) together with establisher's functions for selected allowance organizations and organizational components of the state in the fields of education, culture, transport, health care and social care. The largest transfers of organizations from ministries to regions were performed by the Ministry of Education; out of the total number of transferred organizations (nearly $91 \%$ were educational organizations). Regions also started performing the entrusted functions within the state administration on January 1, 2001.

Subsidies from the state budget were the main source of regional revenues in 2001. These included specific subsidies to regional bodies of representatives (CZK 174.8 mil.) and to regional authorities (CZK 890.2 mil.) (MoF (2001), Part E). On January 1, 2001, the act on budget allocation of taxes became effective ${ }^{5}$ however, the tax revenues were only distributed to municipalities - regions did not obtain any share.

\footnotetext{
${ }^{5}$ Act no. 243/2000 Coll., on Budgetary Determination of Revenues of Some Taxes to territorial self-governing units and some state funds. The act is still valid and was enacted to ensure fiscal sufficiency of particular levels of budgets of territorial self-governing units and at the same time, to expand the range of current tax incomes so that the state budget and the budgets of territorial
} 
At the end of 2001, regions reported a surplus of CZK 0.1 bil. which was deposited on bank accounts. This surplus was mainly represented by specific-purpose means which had not been drawn from, and had to be returned to the state budget within the final financial subsidy accounting. In the year in question, regions seldom accepted loans. The total amount of accepted loans during the year was CZK 2.7 mil. and most of them were paid back during the same year. Regions transferred only CZK 0.7 mil. of unpaid loans to year 2002 (MoF, 2002, Part E).

Year 2002 brought the second stage of the public administration reform which meant the end of district authorities and the transfer of public administration functions from them to municipalities, regions, or ministries. The largest part of establisher's functions of organizations came under the competences of regions, about $84 \%$ out of the total number of transferred organizations. Regional authorities took over 551 organizations, and nearly a half of them (265 organizations) were organizations providing social care services (MoF, 2003, Part E).

From the economic point of view, regions for the first time became recipients of tax revenues - in compliance with the act on budget determination of revenues of some taxes $3.1 \%$ of revenues of shared taxes was allotted to them. Regions thus received their own incomes and could make decisions about how these would be used. At the same time, for the first time they had to cope with an extraordinary situation in their territories - the August floods, which led to a critical situation. In the first half of 2002, the regions were provided a returnable financial support of CZK 0.7 bil. from the chapter General Cash Administration to span the time lag between the collection of taxes and drawing on expenses. The economic activities of regions in 2002 ended with a surplus of CZK 1.8 bil. Their bank account balance was CZK 1.9 bil. (MoF, 2003, Part E).

In 2003, the range of administrative activities and establisher's functions of regions was expanded in relation to the above mentioned end of district authorities. To finance these activities, further subsidies were allotted to regions from the state budget, i.e. the assumed increase in the share of tax revenues did not occur. Regions again managed their activities with a surplus, this time it was CZK 1.5 bil. On the other hand, at the end of the year regions as a whole reported indebtedness of CZK 1.3 bil. However, nearly all liabilities came from the allowance organizations managed by regions, not in the budgets of regions themselves (MoF, 2004, Part F).

Also in 2004, the financing of regions was ensured in the form of subsidies from the state budget, which represented about $80 \%$ of the total income of regions; tax revenues then created only an additional source. In this year an increase in the budget determination of taxes to regions was considered, from the current $3.1 \%$ to $10.32 \%$ of the shared taxes. This was supposed to redistribute means for the performance of the competences of regions from state budget subsidies to tax revenues. However, this was not approved. The economic results of regions in 2004 were again positive, namely CZK 0.8 bil. The bank account balance of regions was CZK 4.3 bil. (MoF, 2005d, Part $\mathrm{E})$.

self-governing units were balanced. 
Year 2005 finally brought a specific change in the budget determination of taxes. The governmental proposal assumed the increase in regions' share of shared taxes from 3.1 $\%$ to $15.06 \%$. However, during negotiations in the House of Representatives of the Parliament of the Czech Republic, the entire field of transfers was removed from the chapter of the Ministry of Education, Youth and Sports and these means were supposed to be even further provided to regions based on subsidy entitlement. Therefore, the resulting share of regions in the shared taxes was decreased to $8.92 \%$; this is valid until today. It means that in 2005 the tax revenues of regions were increased and represented about a third of the entire incomes of regions; nearly two thirds of the incomes came from the subsidies from the state budget. The final economic results of regions were positive again, CZK 0.9 bil. The bank account balance at the end of the year was CZK 6 bil. (MoF, 2005d, Part F).

The indebtedness of regions at the end of 2005 increased to CZK 2.9 bil., which in comparison with the previous year represents an increase of more than $90 \%$. The most frequently used debt instruments were loans and returnable financial supports from the state budget and the budget of state funds. Regions did not issue any communal bonds. From the perspective of the regional indebtedness control mentioned above, all regions achieved a low debt service indicator in 2005. At the same time, they started preparing projects for the construction and reconstruction of the neglected road network in regions; that is why as early as in 2005 they negotiated the possibilities and conditions of loans from the EIB (European Investment Bank) in advance. The drawing of these means is usually distributed into several tranches with the maturity from 3 to 20 years. Further, some regions accepted loans from commercial entities (specifically Ceska sporitelna) for pre-financing or co-financing of individual projects (MoF, 2006, Part F).

In 2006, the sum budget of regions was proposed with the deficit for the first time; the proposed deficit was CZK 1.5 bil. This meant the means for covering the deficit had to be provided for in advance, as is stipulated in budget regulations for territorial selfgoverning units. The decision on a specific instrument depends on the choice of the regional representatives. At the end of the year, the deficit was higher than the expected amount, about CZK 2.2 bil. At the same time, the regions had CZK 7.5 bil. on bank accounts. The indebtedness of regions climbed to CZK 7.7 bil. at the end of the year, which compared to the previous year was a rise of over $160 \%$. The main rise was brought about by loans; regions did not issue communal bonds again. Loans were mainly accepted from the EIB and used for the infrastructure projects mentioned above but other loans were accepted from local commercial banks (MoF, 2007, Part F).

Also for the year of 2007, regions planned economic results with a deficit, in the amount of CZK 2 bil. However, the final economic result was a surplus of over CZK 1 bil. There was no considerable change in the structure of revenues and expenditures; the better results of regions were helped partially by the strong economic growth. At the end of the year, regions had debts in the amount of $\mathrm{CZK} 10.4$ bil., i.e. the trend of growing indebtedness continued. Loaned sources were again used for infrastructure projects or pre-financing of EU projects, to a smaller degree for settling debts of regional hospitals. The main creditors were again the EIB and some local commercial banks (Ceska Sporitelna, Komercni banka). Regions also accepted loans and specificpurpose transfers from the SFTI (The State Fund for Transport Infrastructure) for the 
financing of the transport infrastructure in the total amount of CZK 0.6 bil. (MoF, 2008, Part F).

The end of 2008 brought deceleration of the economic growth. The budget of regions was again proposed with a deficit, this time in the amount of CZK 1.5 bil. The final economic result was a lower deficit - CZK 1.2 bil. The balance of financial means in bank accounts of regions was CZK 14 bil. The indebtedness of regions including their allowance organizations continued with a growing tendency, to the amount of CZK 14.6. bil. The highest increase was again reported for the item of loans, regions did not issue communal bonds. The main partners in the field of loans again included the EIB for the projects of construction and reconstruction of regional infrastructure, other partners were local commercial banks (Ceska Sporitelna, Komercni banka) for the purposes of pre-financing of projects from the EU. Also in this year regions took loans and transfers from the SFTI in the total amount of CZK 2.6 bil., out of which CZK 0.9 bil. were interest-free loans for pre-financing of expenses (MoF, 2009, Part F).

In 2009 the Czech economy was in the recession, which was a relatively new situation for regions and affected their economic activities substantially. However, thanks to the structure of revenues of regions, where the predominating source is subsidies, the impact on regional budgets was not as large as in case of e.g. municipal budgets. The lower collection of taxes was partially compensated to territorial budgets by the increase in transfers from the state budget and state funds. At the same time, regions had to involve their financial reserves and cut expenditures. At the beginning of the year a surplus budget in the amount of CZK 1.9 bil. was approved but the resulting balance at the end of the year was negative CZK 7.7. bil. The balance on bank accounts also decreased by CZK 2.7 bil. due to the use of reserves (MoF, 2010c, Part F).

The negative balance of regions' economic activities was also reflected in the increased indebtedness of regions (including their allowance organizations). The debt reached CZK 20.9 bil. at the end of 2009. The main instruments were loans again; their share of the total indebtedness was $83.4 \%$. Regions again did not issue communal bonds, none of the regions has used this option for covering its deficit yet (unless we consider the capital of Prague). Some regions continued their cooperation with the EIB concerning financing of large investments in the regional infrastructure (reconstructions of $2^{\text {nd }}$ and $3^{\text {rd }}$ class roads, roadside facilities), tourism, science and research. Regions accepted more loans from Czech banks to pre-finance investment projects or repairs of roads. Even in the "year of crisis" regions received interest-free loans from the SFTI for prefinancing of EU projects of transport infrastructure, in the amount of CZK 1.1 bil. (MoF, 2010c, Part F). Thus we can say that the regions attempted to maintain the necessary development investments in spite of the increased lack of income sources in 2009 (Vývoj zadluženosti obcí a krajů do roku 2009).

The development of the indebtedness of regions during the entire explored period is presented in Table 5. Besides the nominal amount of the debt in billions of CZK, the table shows the proportion of the regional indebtedness in the GDP, or in the debt of the Czech government sector. These numbers are not alarming yet, at the end of 2009 the indebtedness of regions had a proportion of mere $1.6 \%$ of the government debt, which indicates that it is not the main obstacle to meeting the Maastricht fiscal criterion of debt volume. The dynamics of the debt growth is more warning. 
Table 5: Indebtedness of Regions (including their allowance organizations)

\begin{tabular}{|l|c|c|c|c|c|c|c|c|c|}
\hline & 2001 & 2002 & 2003 & 2004 & 2005 & 2006 & 2007 & 2008 & 2009 \\
\hline $\begin{array}{l}\text { Indebtedness of regions } \\
\text { (in bil. CZK) }\end{array}$ & 0.0 & 0.0 & 1.3 & 1.5 & 2.9 & 7.7 & 10.4 & 14.6 & 20.9 \\
\hline $\begin{array}{l}\text { Indebtedness of regions } \\
\text { (in \% of GDP) }\end{array}$ & 0.0 & 0.0 & 0.1 & 0.1 & 0.1 & 0.2 & 0.3 & 0.4 & 0.6 \\
\hline $\begin{array}{l}\text { Indebtedness of regions } \\
\text { (in \% of government } \\
\text { debt) }\end{array}$ & 0.0 & 0.0 & 0.2 & 0.2 & 0.3 & 0.8 & 1.0 & 1.3 & 1.6 \\
\hline $\begin{array}{l}\text { Dynamics of } \\
\text { indebtedness }\end{array}$ & - & - & $4332 \%$ & $15 \%$ & $93 \%$ & $166 \%$ & $35 \%$ & $40 \%$ & $43 \%$ \\
\hline
\end{tabular}

Source: CSO (2010), MoF (2010c); calculation of the dynamics of indebtedness - the author.

Table 6 shows the differences between the balances in current accounts of regions and their allowance organizations and the amount of debt. We can see that the difference is positive in all the explored years, ranging above CZK 10 bil. since 2003. The last year 2009 meant a substantial decrease in the surplus, to CZK 1.2 bil. (the surplus occurred mainly thanks to the reserves of allowance organizations of regions) (MoF, 2010c, Part F).

Table 6: Indebtedness of Regions and the Balances of Their Current Accounts (including their allowance organizations)

\begin{tabular}{|l|c|c|c|c|c|c|c|c|c|}
\hline In bil. CZK & 2001 & 2002 & 2003 & 2004 & 2005 & 2006 & 2007 & 2008 & 2009 \\
\hline Indebtedness & 0.0 & 0.0 & 1.3 & 1.5 & 2.9 & 7.7 & 10.4 & 14.6 & 20.9 \\
\hline Balance of current account & 4.4 & 6.9 & 12.5 & 13.1 & 15.1 & 17.8 & 21.0 & 24.9 & 22.1 \\
\hline Difference & 4.4 & 6.9 & 11.2 & 11.6 & 12.2 & 10.1 & 10.6 & 10.3 & 1.2 \\
\hline
\end{tabular}

Source: $M o F$ (2010c, Part F, p. 332).

\section{The Practice of Liabilities and Fiscal Risk Management in the Regions of the Czech Republic}

The interviews were conducted by the research team of the Department of Public Economy, Faculty of Economy and Administration, Masaryk University, from June to September 2010. Their results concerning fiscal imbalance of regions and its management are further analyzed in the text. They revealed interesting facts which would not be gained from other sources, especially regarding the view of the activity/passivity of liabilities management at the regional level, and the range of tools used for the management of fiscal risks.

According to the theoretical concept, we have to understand an active management of a debt as an effort to cut debt operational expenses by the means of financial market instruments, optimization of the structure of debt instruments, i.e. "short" and "long" money diversified in the context of expenses vs. risks - not only proper settlement of loans accepted. The text that follows will show us that most regional representatives perceive an active debt management also as a proper meeting of contracts on loans and their proper settlement.

As regards fiscal risks (refinancing risk, interest rate risk, liquidity risk, currency risk, counterparty risk, etc.), the main instruments for their management are e.g. schedule of installments, the risk map, or the risk matrix, which also takes into consideration loans 
and guarantees provided by the regions and evaluated by a coefficient. The degree of use of these instruments differs in individual regions, as the following text shows.

The interviews showed one more interesting fact: the data provided by the regions themselves concerning their own indebtedness do not really agree with the data published by the MoF (partially, the difference can be caused by inclusion/exclusion of the liabilities of allowance organizations in/from the resulting sum of regional liabilities). Also the interpretation of indebtedness in the materials of the MoF (e.g. State Financial Statements) and by individual representatives of regions differs slightly. Whereas the MoF documents point out the growing tendency of regional indebtedness and the associated risks, regions themselves see the situation more positively, mainly because most of their liabilities are related to their investment activities, not financing of common needs. The reasons for the deficits thus comply with the recommendations of the theory of public finances which "allows" liabilities only on condition of the financing of investment activities and the subsequent possible return of financial benefits of these investments for the budget. The distribution of liabilities among individual regions is presented in Table 7. It shows that with the exception of the Pilsen region each region has some liabilities.

Table 7: Indebtedness of Individual Regions (2005-2009)

\begin{tabular}{|l|c|c|c|c|c|}
\hline Region & 2005 & 2006 & 2007 & 2008 & 2009 \\
\hline Central Bohemian & - & - & 0.00 & 0.93 & 2.94 \\
\hline Hradec Kralove & 0.28 & 0.58 & 0.84 & 1.06 & 1.14 \\
\hline Karlovy Vary & 0.42 & 0.73 & 0.62 & 0.97 & 0.98 \\
\hline Liberec & 0.28 & 0.68 & 0.92 & 1.11 & 0.98 \\
\hline Moravian-Silesian & 0.17 & 0.61 & 0.83 & 1.29 & 1.10 \\
\hline Olomouc & 0.08 & 0.55 & 0.95 & 1.78 & 2.31 \\
\hline Pardubice & 0.77 & 1.25 & 1.90 & 2.17 & 2.43 \\
\hline Pilsen & 0.01 & 0.00 & 0.00 & 0.00 & 0.00 \\
\hline South Bohemian & 0.04 & 0.42 & 0.81 & 0.64 & 0.96 \\
\hline South Moravian & 0.43 & 1.70 & 1.90 & 2.40 & 2.44 \\
\hline Usti & 0.09 & 0.19 & 0.30 & 0.42 & 1.97 \\
\hline Vysocina & 0.05 & 0.21 & 0.55 & 0.71 & 1.84 \\
\hline Zlin & 0.25 & 0.77 & 0.74 & 1.12 & 1.75 \\
\hline Total & 2.88 & 7.68 & 10.36 & 14.59 & 20.85 \\
\hline
\end{tabular}

Source: Journal of Public Administration (2010, August 9).

In the following text, attention is devoted to individual regions of the Czech Republic and to an analysis of the results gained in the interviews. The first region mentioned is the capital of Prague which has a specific position among the regions of the CR; the following sections on regions are ordered alphabetically. Finally, the facts are generalized and conclusions and recommendations are formed.

\section{Capital of Prague}

The capital of Prague has a debt of about CZK 25 bil.; for comparison, the total volume of the budget is about CZK 60 bil. Rating agencies consider Prague to be a debtless city (see the rating of agencies published on webpages of the Prague Council - Portal of 
Prague (2010)). The debt is managed actively according to a Council representative. The portfolio includes liabilities in foreign currencies, i.e. currency risks are provided for, further interest rate risks. To manage the risks swap operations and derivates are used. There is a special department within the Budget Department which deals with the management of the debt service, investments of temporarily free financial means, etc. Sometimes there occurs cooperation with expert private companies, but not with the MoF. Prague also settles its debt actively, e.g. in 2009 it paid CZK 7 bil. of bonds; during July 2010 further CZK 4 bil. were paid. During the last four years the debt dropped from CZK 33 bil. to the current CZK 25 bil.approximately. Monitoring of risks related to each department is the used tool of fiscal risk management. Each department has defined risk indicators; these are filled in a form for the entire Council. The monitoring and evaluation of risks is a responsibility of the Department of Internal Audit, which deals with the entire Council. Schedules of installments represent another important tool of fiscal risk management in the Capital of Prague.

\section{Central Bohemian Region}

The indebtedness of the Central Bohemian region at the end of 2009 reached CZK 2.5 bil. According to the representatives, the region has an active management of the debt. The region has only one loan accepted in 2007, and is drawn on gradually. Before its acceptance the conditions of other financial tools were also examined. As a result, the current loan contract for CZK 4 bil. was approved. The amount of the loan is not transferred to the region's account as a whole - only amounts which are necessary are transferred on the region's account on the basis of the Council approval. By 2008 the region had drawn CZK 920 mil., in 2009 it was CZK 1.56 bil., and it was assumed that all of the loan would be drawn in 2010. The settling of the loan started in 2010. The loan was used for transport and construction of roads and partially for subsidies within the environment, specifically for construction of sewage system. Schedule of installments is the used instrument of risk management. According to a region's representative, the issuance of communal bonds is not considered because that would be a more expensive version of obtaining financial means. The representative is of the opinion that the region could use communal bonds as a political rather than an economic instrument, e.g. if the bonds were purchased by the inhabitants of the Central Bohemian region itself.

\section{Hradec Kralove Region}

The indebtedness of the Hradec Kralove region exceeded CZK 1 bil. at the end of 2009. This contains two loans from a commercial bank with the maturity period of eight years; the loans were selected based on a competitive tendering for a public order with the participation of the Ministry of Finance. The region settles its liabilities in agreement with its schedule of installments to the financial institution which according to a region's representative offered better conditions than the EIB. The main advantage is that the region does not have to co-finance $50 \%$ of means from its own resources but uses loan financing or means from the SFTI. 


\section{Karlovy Vary Region}

The Karlovy Vary region reports indebtedness of about CZK 1.8 bil. Out of this, there are two loan frameworks of CZK 1.3 bil. for the purposes of projects and the pavilion of acute medicine and central entrance, CZK 500 mil. will be paid from the regional budget. At the moment, CZK 350 mil. have been drawn from the first and CZK 10 mil. from the second loan framework, the loans are being paid back at the same time. The loans were obtained from commercial banks on the basis of a competitive tendering. The EIB has not applied for the competitive tendering and the region's representatives did not address the EIB because the region does not draw means from this institution. As regards risk management, the Karalovy Vary region is considering fixation of interest rates. In the meantime, floating interest rates are used for the loans, connected to discount rates of the Czech National Bank. This is of advantage at the moment - the expected expenses on interests have dropped since 2007, when the loan was concluded, by CZK 100 mil. a year thanks to floating rates. However, there are some worries concerning further development. At the time of the interview, the decision regarding the change of interest rates was not been made yet. The region does not follow any other fiscal risks. It provides guarantees to its allowance organizations only, and the funds from surpluses are created for reserves.

\section{Liberec Region}

The indebtedness of the Liberec region reached CZK 1.5 bil. at the end of 2009. Out of this, CZK 750 mil. was a loan for road maintenance, CZK 100 mil. was a loan for a dining unit in the regional hospital, and at the time of the interview, the region was planning to accept another loan for bridge construction at an amount of CZK 500 mil.. The selection of loan providers is conducted according to the standard regime on the basis of the act on public orders. The region does not take a loan from the EIB because - according to the region's representative - the obtained loans are of nearly the same conditions as the EIB provides. The region representative is of the opinion that this is caused by the fact that the region has a good position, banks respect it and try to offer advantageous conditions. The Liberec region has explored its situation among the regions of the $\mathrm{CR}$ and found out that there are both better and worse regions from the point of view of interest expenses. If they decided to accept a loan from the EIB, a new competitive tendering would have to be announced for the debt refinancing. During the interview no information was gained concerning instruments of fiscal risk management; in other words, these instruments are probably not being used.

\section{Moravian-Silesian Region}

The debt of the Moravian-Silesian region was about CZK 1.1 bil. at the end of 2009. This was a typical loan provided by the EIB. In 2010 the region paid back CZK 110 mil. which reduced its indebtedness. Further CZK 7 mil. are loaned from the SFTI - this is an interest free loan for pre-financing of EU projects for road constructions. According to the region's representative, the region has only one debt towards a commercial institution and that is again for pre-financing of projects. This loan was accepted on the basis of a competitive tendering in which the cheapest product was used in compliance with valid regulations. Its form is a bank overdraft, i.e. it is an operative loan. As the region's representatives assumed, there would be a negative balance in the account at 
the end of the year but it would be only a short-term financial support. As an instrument for debt management a schedule of installments is used, fiscal risks are not managed in any special way.

\section{Olomouc Region}

The Olomouc region reported the debt of CZK 1.5 bil. at the end of 2009. According to the region's representative, the region is trying to manage its liabilities actively, by the means of loan minimization. But this is in contrast to the region's philosophy which asserts the efforts to make investments. This is quite a complicated compromise when the region tries to choose suitable loan products so that investments are not in danger, and at the same time the region is overindebted. Moreover, the region tries to settle the loans every year, currently the debt service is CZK 250 mil. per year. Further, the region's representative named various economical measures towards unions as the region's effort to manage indebtedness. When drawing up a budget, first the means for the debt service are distinguished, and only then the budget for other items is created. As risk management is concerned, the region's representative mentioned the setting of different interest rates for tranches of the loan from the EIB. All risks are provided for in the agreement with the EIB, therefore, the region has no need to manage fiscal risks or create risk matrixes. The region accepted the loan from the EIB because there is the opinion that it is a cheap loan, i.e. the EIB offered the most advantageous conditions and also risk management.

\section{Pardubice Region}

The debt of the Pardubice regions at the end of 2009 was about CZK 2.5 bil.. A part of the debt, about CZK 400 mil., was used for settlement of debts of regional hospitals; another CZK 1.2 bil. was used for pre-financing of EU projects and investments. However, the region needs to find additional CZK 2.5 bil. for co-financing in its resources because co-financing cannot be settled from loaned sources only. The Pardubice region has one of the highest capital expenditures/total expenditures ratios of the approved budget. In some years these reached up to $25 \%$ of the budget. The used instruments of debt management are schedules of installments as negotiated with creditors. The loans and interests are settled with priority from the budget. The region also accepted an interest-free loan from the SFTI but it is only a short-term loan which will be settled when the subsidies from the EU are obtained.

\section{Pilsen Region}

The Pilsen region was the only one which did not have any debt at the end of 2009. At the moment of the interview, the representatives were about to approve the demand to accept a bridging loan at an amount of about CZK 300 mil.; negotiations about the possible provider, whether use a commercial loan or a loan from the EIB, were in progress. This loan will probably be used for co-financing of EU projects, until now the region has made do with its own resources. Because of the zero indebtedness, no risk management instruments are used. No region guarantees are reported. Financial means from surpluses are deposited in term accounts - the specific product was selected by the economic deputy. 


\section{South Bohemian Region}

The debt of the South Bohemian region at the end of 2009 amounted to about CZK1 bil.. According to its representatives, the South Bohemian region makes the effort to manage liabilities actively; by active management they mean the optimization of the structure of debt instruments, use of schedule of installments, or premature settlement of liabilities (loans), if this is more advantageous than let them finish naturally. Further, the interest rates of deposits on current or term accounts are monitored, or there are efforts to manage free financial means so that they were valorized as much as possible. Besides the schedule of installments mentioned above, postponement of drawing is also used as an instrument of fiscal risk management, if this seems to be advantageous at the moment because it is sometimes cheaper for a region to use a bank overdraft than a more expensive loan.

\section{South Moravian Region}

The indebtedness of the South Moravian region was about CZK 2.5 bil. at the end of 2009. The region proclaims an active liability management. The main form is a gradual drawing of loans in compliance with stipulations of the agreement with the EIB. The first loan framework of CZK 1.2 bil. was being drawn on until the end of 2009. Now a new loan framework is to be drawn on, in the volume of CZK 2 bil., with drawing of individual tranches until 2013, or 2015. This is aimed on an implementation (cofinancing) of EU projects. An agreement was concluded with the EIB due to an advantageous interest rate. If a tranche is used, the interest rate is established as fixed. Allowance organizations founded by the region have loans from commercial banks as well (management and maintenance of roads, hospitals). An acceptance of a loan is preceded by a competitive tendering which is determined mainly by the "price" of the loan, i.e. the interest rate. The South Moravian region does not monitor its guarantees because it gave only a minimal number of them. The used instrument of fiscal risk management is the schedule of installments only because the agreement with the EIB contains appropriate financial indicators, including regulation elements.

\section{Usti Region}

The indebtedness of the Usti region at the end of 2009 was about CZK 2 bil. The debt consisted of two loans with a fixed interest rate and one, the largest, loan framework for pre-financing of EU projects with a variable interest rate. The loans are accepted from local banks (Ceska sporitelna, Komercni banka). The loan framework is set to CZK 2.5 bil., the region has drawn CZK 1.5 bil. so far. Only interests have been paid, the loan itself will be settled after the means from EU funds have been obtained. According to a region's representative, the region has no need to manage its liabilities and does not use fiscal risk management.

\section{Vysocina Region}

The debt of the Vysocina region at the end of 2009 was about CZK 700 mil., which makes the region one of those with lower indebtedness. However, in 2010 another loan contract was signed for CZK 0.5 bil. and a region's representative assumed that the debt would climb to CZK 1 bil. by the end of year. Besides, the region can draw from a bank 
overdraft, where at the end of 2009 CZK 508 mil. were drawn; before March 2010 this was settled as a consequence of accepted subsidies. These means were used for prefinancing of EU projects. The loans were accepted from the EIB and there is one loan from the SFTI in relation to European projects. The first loan from the EIB was used for repairs of roads, not for the financing of EU projects. The second loan from the EIB, which the region started drawing on in 2010, was partially used for the European fund and partially for the region's investment intentions. The EIB loan of 2006 has a variable interest rate, at the time of the interviews the rate was $1.39 \%$. The settlement of the loan is distributed into 20 years, the payments of interests and principal are done every half a year. Before accepting the loan from the EIB the region explored more options and the EIB came out as the most advantageous. Besides the advantageous conditions, the region's representative also mentioned the fact that with a foreign bank no competitive tendering in compliance with act on public orders is necessary, while in case of a local bank competitive tendering is necessary. As regards fiscal risk management, the region does not operate in financial markets. In the past it attempted to invest free financial means based on cooperation with professional teams which managed the region's portfolio. However, the region was not satisfied with the cooperation with them due to little return from one team and also because of risk investments, the region's representatives decided to end these activities. At the moment the region does not have any free resources which could be invested at capital markets. And according to the region's representative, a region is not an entity that should operate in the market. They could hire a professional who would manage the debt and optimize interests. However, such a person is not at the region's disposal at the moment and with respect to the region's low indebtedness, this is not the region's priority.

\section{Zlin Region}

The indebtedness of the Zlin region is about CZK 2 bil.. The interview showed that there is no active management of the debt, or rather that the representatives consider proper payment of liabilities in agreement with schedules of installments to be an active debt management. The schedules of installments have been set for long-term liabilities (loans from the EIB and Ceska Sporitelna). For the liabilities from economic activities, the minimum maturity period of 30 days is maintained. As an instrument of fiscal risk management, indicators of indebtedness are assessed according to the EIB methodology before the loan is drawn on; further, the currency risk is managed.

\section{Conclusions}

The presented results of interviews clearly showed different attitudes to debt and risks management at the regional level in the Czech Republic. An active debt management, as defined by the theory, has not been encountered by any of the Czech regions (except for the capital of Prague), although their representatives are convinced otherwise. However, it is necessary to note that the indebtedness of regions is at a relatively low level when compared with e.g. the central government, that is why no pressure is created here on active work with regional indebtedness. In comparison to the central level, there is also a big difference in the usage of the loaned sources. While the regions incur debts only because of implementation of investment projects, the central government uses debts to cover its common expenditures as well. In this respect, the situation of the managers of 
the state debt is more complicated as their primary aim is to secure loan needs of the government and only then minimize expenses. At the regional level, the amount of expenses related to a loan is dealt with in advance, usually within the competitive tendering; it means the minimization of expenses should be ensured when the loan contract is being concluded. The amount of interest rates offered changes with time, and thus it would be recommendable to consider refinancing of a loan with another loan in a longer term. However, interest rates do not represent any real burden to the regions at the moment, so they do not seek for the ways to decrease them. Moreover, a competitive tendering would be necessary.

The main loan partner of about a half of the regions is the EIB, which provides them with financial means for investment activities. In some cases these resources are used for pre-financing of projects co-financed from EU funds, in other cases these are individual investments of regions without any relation to European funds. The interviews showed that advantageous conditions of the financial mean provision are a frequent reason why regions use the EIB. Its advantageous character follows from more facts. The first advantage is represented by a relatively low interest rate on loans when compared with other bids. Providing of the resources in more tranches, i.e. the region can draw only as much as it needs at a moment, is another advantage. Still another advantage is the possibility to postpone payments thanks to which the region uses the means directly but starts paying back after several years. It is also important to remember that the loan contracts with the EIB already contain the management of risks, therefore, it is not necessary to deal with this individually. Last but not least, in compliance with the act on public orders when the financial means are provided from abroad, no competitive tendering is necessary.

The other regions use loan services of local commercial banks, mostly Ceska sporitelna and Komercni banka. In compliance with the act on public orders, the intention to accept a loan has to be announced and a competitive tendering has to be organized. Regions are good clients, they usually guarantee with their property or future tax revenues, therefore banks are willing to lend them their means, and if necessary to offer individual conditions, too. These financial sources are also usually used for investments in the development of the region. A special instrument used for a potential temporary discrepancy between revenues and expenditures of a regional budget is a bank overdraft loan. Nearly all regions have the kind of account which provides this option and use it if it seems better from the perspective of expenses.

Communal bonds at the level of regions have not been issued, if we omit the capital of Prague. The reason according to the representatives of regions is the demanding character of this instrument and the necessity to use a mediator. The volume of issued bonds has to range in much higher amounts than the regions actually need if the issuance is to pay off. Although we can expect an interest of investors in purchasing regional bonds, the regions are not considering issuance of any.

Generally spoken, the regions operate in financial and capital markets only seldom. Except for the capital of Prague, only a minority of the regions have experience with the usage of market instruments such as swaps or repo operations. Temporarily free financial means are often deposited to term accounts or just "lie" on bank accounts. Several regions have tried to invest these means in the market, but due to disputable 
results and the necessity to hire professionals for this activity, they abandoned this idea. The interviews showed that at the moment, there are not many experts in financial markets or debt management working at Regional Authorities, which only confirms that these areas are not in the focus of interest of regions. On the other hand, there are many experts dealing with the management of the budget and the related risks. Although risk maps or risk matrixes are not usually created, the risks connected with the regional budgets are monitored (especially currency risks and interest rate risks) and solved if necessary. As has been mentioned before, neither this is an area which would be a "hot issue" for regions at the moment.

\section{References}

Act No. 129/2000 Coll. on Regions

Act No. 243/2000 Coll. on Budgetary Determination of Revenues of Some Taxes

Act No. 250/2000 Coll. on Budgetary Rules for Local Governments

Act No. 320/2001 Coll. on Financial Control in Public Administration

Czech Statistical Office (2010). Czech Republic: Main Macroeconomic Indicators. Retrieved November 27, 2010, from http://www.czso.cz/csu/redakce.nsf/i/cr:_makroekonomicke_udaje/\$File/AHLMAKRO. xls

Czech Statistical Office (2010b, October 29). Demographic Yearbook of the Czech Republic 2009. Retrieved November 20, 2010, from http://www.czso.cz/csu/2010edicniplan.nsf/p/4019-10

DVOŘ́́KOVÁ, P. (2007). State Regulation of the Municipal Debt in the Czech Republic. In Debt Management in Transition Countries: Experience and Perspectives. 1. vyd. Bratislava : NISPAcee, 2007. od s. 76-92, 17 s. ISBN 978-80-89013-33-3;

DVOŘÁKOVÁ, P. (2009). Fiskální nerovnováha krajů a její řízení. In ŠELEŠOVSKÝ, J. a kol. Management veřejných financí krajské samosprávy. 1. vyd. Brno : ESF MU, 2009. od s. 90-108, 19 s. ISBN 978-80-210-5096-9.

DVOŘÁKOVÁ, P. (2010). Řízení krátkodobé a dlouhodobé nerovnováhy krajů. In Hospodaření krajské samosprávy. 1. vyd. Brno : Masarykova univerzita, 2010. od s. 121-144, 24 s. ISBN 978-80-210-5423-3;

Interview Survey within Project GAČR No. 402/08/1158 (2010). Implementace nových nástrojů ř́zení veřejných výdajů na regionální úrovni v ČR. Brno: Masaryk University, Faculty of Economics and Administration.

MEDVEĎ, J. et al. (2005). Verejné financie. 1. ed. Bratislava: SPRINT vfra, 464 p., ISBN 80-89085-32-2.

Ministry of Finance of the Czech Republic (2002). State Financial Statement for the year 2001 .

Ministry of Finance of the Czech Republic (2003). State Financial Statement for the year 2002.

Ministry of Finance of the Czech Republic (2004). State Financial Statement for the year 2003. 
Ministry of Finance of the Czech Republic (2005a). Makroekonomická predikce. Retrieved September 7, 2009, from http://www.mfcr.cz/cps/rde/xchg/mfcr/xsl/makro_pre.html

Ministry of Finance of the Czech Republic (2005b). Monitoring hospodaření obcí. Retrieved November 20, 2010, from http://www.mfcr.cz/cps/rde/xchg/mfcr/xsl/vf_monitoring_hospodareni_obci.html

Ministry of Finance of the Czech Republic (2005c). Regulace zadluženosti obcí a krajů - ukazatel dluhové služby. Retrieved November 20, 2010, from http://www.mfcr.cz/cps/rde/xchg/mfcr/xsl/ver_rozpocty_12197.html?year=2008

Ministry of Finance of the Czech Republic (2005d). State Financial Statement for the year 2004 .

Ministry of Finance of the Czech Republic (2006). State Financial Statement for the year 2005 .

Ministry of Finance of the Czech Republic (2007). State Financial Statement for the year 2006.

Ministry of Finance of the Czech Republic (2008). State Financial Statement for the year 2007.

Ministry of Finance of the Czech Republic (2009). State Financial Statement for the year 2008.

Ministry of Finance of the Czech Republic (2010a) ARIS web. Presentation of Data of Territorial Self-governing Units. Retrieved November 20, 2010; from http://wwwinfo.mfcr.cz/cgi-bin/aris/iarisusc/index.pl

Ministry of Finance of the Czech Republic (2010b). Draft of the State Budget for the Year 2011.

Ministry of Finance of the Czech Republic (2010c). State Financial Statement for the year 2009.

Ministry of Finance of the Czech Republic (2011). State Financial Statement for the year 2010 .

Ministry of Finance of the Czech Republic, Audit Department - Central Harmonisation Unit (2004, April). Pokyn k jednotnému uplatňování závazných pravidel a doporučení pro systém řizení rizik v orgánech veřejné správy. Retrieved September 6, 2009, from http://www.mfcr.cz/cps/rde/xchg/mfcr/xsl/verspr_kontrola_8562.html

Portal of Prague (2010). Rating hl.m.Prahy. ”Retrieved November 20, 2010, from http://magistrat.praha-mesto.cz/Rozpocet/Dluhopisy-hl-m-Prahy\#Rating_hl.m.Prahy

SEVERA, J. (2004). Řízení rizik a moderní interní audit. “ Retrieved November 27, 2010, from http://www.kr-vysocina.cz/soubory/450008/intaudariznakru_6_04II.pdf

ŠVEC, P. (2009). Řízení fiskálních rizik (na úrovni krajských rozpočtů ČR). Diploma Thesis. Brno: Masaryk University, Faculty of Economics and Administration. Department of Public Economics. 83 p.

Vývoj zadluženosti obcí a krajů do roku 2009. (2010, August 9). Deník veřejné správy. Retrieved November 27, 2010, from http://denik.obce.cz/go/clanek.asp?id=6441251 
Appendix 1: System of Informative and Monitoring Indicators applied on the

Czech Regions (31. 12. 2009)

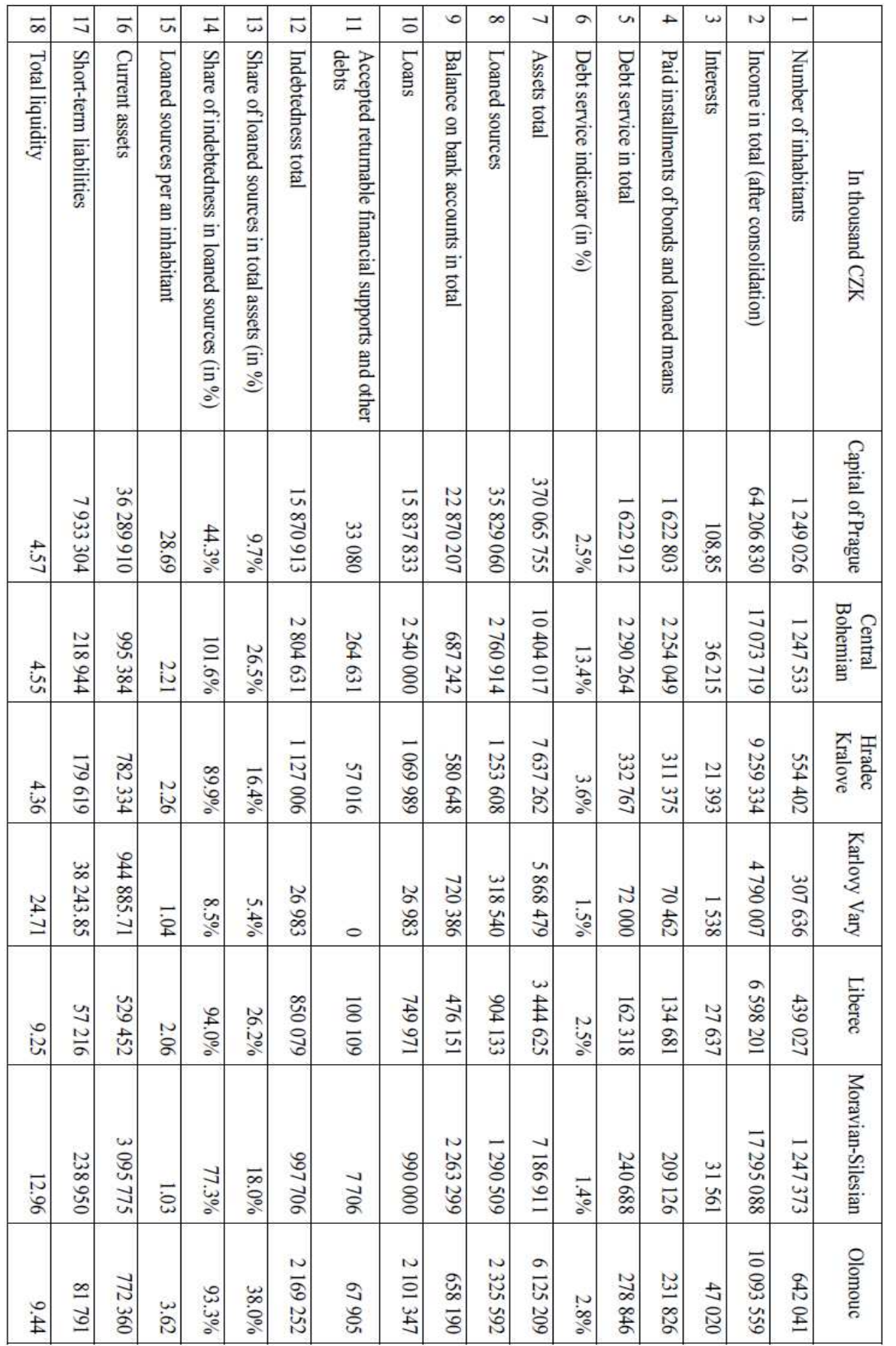




\begin{tabular}{|c|c|c|c|c|c|c|c|c|c|c|c|c|c|c|c|c|c|c|}
\hline $\bar{\infty}$ & $\Xi$ & $\sigma$ & $\bar{v}$ & $\mp$ & $\bar{\omega}$ & $\bar{N}$ & $=$ & $\bar{\sigma}$ & 0 & $\infty$ & 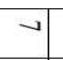 & & 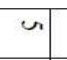 & + & $\omega$ & $N$ & - & \\
\hline 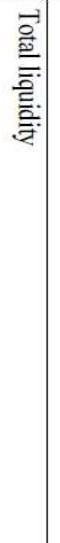 & 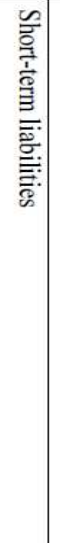 & 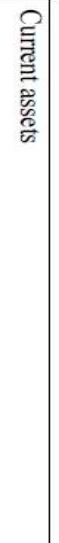 & 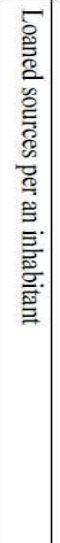 & 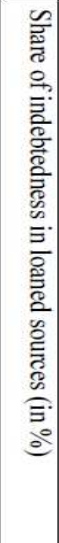 & 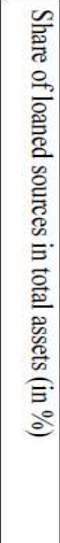 & 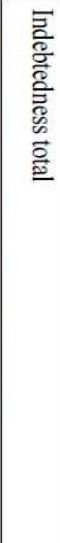 & 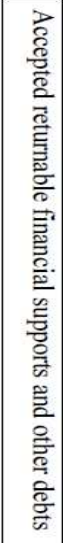 & $\begin{array}{l}\overline{5} \\
\bar{w} \\
\bar{v}\end{array}$ & 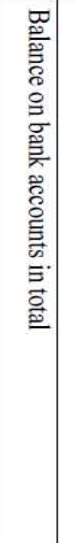 & 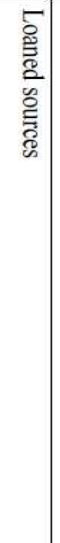 & 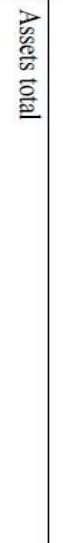 & 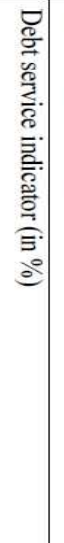 & 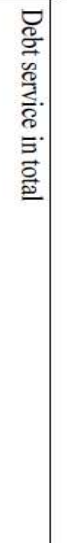 & 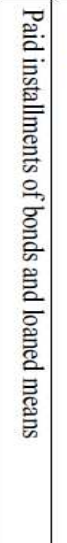 & 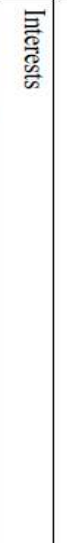 & 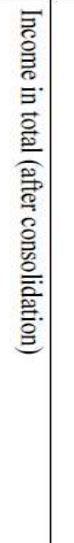 & 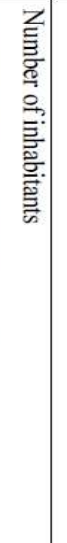 & 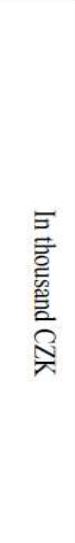 \\
\hline$\vec{\phi}$ & $\begin{array}{l}\overrightarrow{0} \\
+ \\
\text { ta }\end{array}$ & 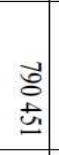 & $\stackrel{ \pm}{\exists}$ & $\begin{array}{l}8 \\
\text { to }\end{array}$ & 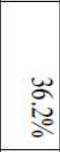 & 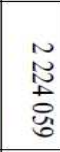 & $\underset{\stackrel{ \pm}{ \pm}}{\stackrel{ \pm}{ \pm}}$ & $\begin{array}{l}\vec{v} \\
\vec{b} \\
\vec{w} \\
\vec{u}\end{array}$ & $\begin{array}{l}\breve{u} \\
\vdots \\
\vdots\end{array}$ & 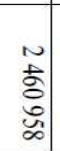 & 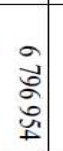 & $\vec{t}$ & 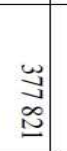 & $\begin{array}{l}\text { 芯 } \\
\text { 总 }\end{array}$ & $\begin{array}{l}\breve{.} \\
\stackrel{心}{心}\end{array}$ & 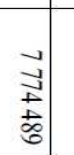 & 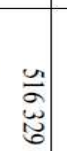 & 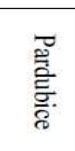 \\
\hline$\frac{n}{0}$ & $\begin{array}{l}\overrightarrow{.} \\
\stackrel{5}{6} \\
\end{array}$ & 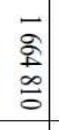 & $\stackrel{\circ}{=}$ & : & $\overrightarrow{\vec{d}}$ & 0 & 0 & 인 & $\begin{array}{c}\vec{a} \\
\vec{\omega} \\
\vec{x} \\
\infty\end{array}$ & 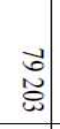 & 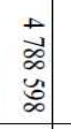 & $\therefore$ & 0 & 0 & 0 & 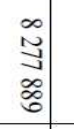 & 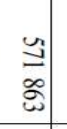 & 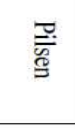 \\
\hline $\begin{array}{l}+ \\
\dot{\infty}\end{array}$ & $\begin{array}{l}\vec{g} \\
\stackrel{0}{a} \\
\vec{a}\end{array}$ & | & $\overline{\mathbf{9}}$ & 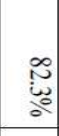 & $\begin{array}{l}\text { L } \\
\text { to }\end{array}$ & 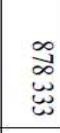 & 0 & 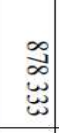 & $\begin{array}{l}\stackrel{a}{\leftrightarrow} \\
\stackrel{0}{2}\end{array}$ & $\underset{:}{\stackrel{\Xi}{0}}$ & 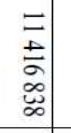 & $\therefore$ & \begin{tabular}{c|c|c|c|}
8 \\
\\
$\vdots$ \\
\end{tabular} & 索 & $\begin{array}{l}\vec{\partial} \\
\infty \\
\dot{\omega}\end{array}$ & 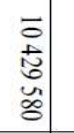 & 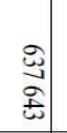 & 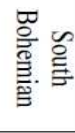 \\
\hline$\dot{\sigma}$ & $\begin{array}{l}\text { ్. } \\
\text { \&े }\end{array}$ & $\begin{array}{l}\text { ज्ञ } \\
\text { ff }\end{array}$ & iे & $\begin{array}{l}\infty \\
\stackrel{+}{0} \\
\frac{1}{0}\end{array}$ & 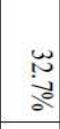 & 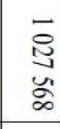 & $\vec{⿱}$ & $\begin{array}{l}\text { : } \\
\text { : } \\
\text { \&े }\end{array}$ & 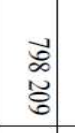 & $\begin{array}{l}\overline{\vec{ज}} \\
\vec{\Xi} \\
0\end{array}$ & $\begin{array}{l}\omega \\
\vec{\sigma} \\
\infty \\
\infty \\
\infty\end{array}$ & $\overline{\overline{0}}$ & $\begin{array}{l}\vec{u} \\
\vec{u} \\
\end{array}$ & $\begin{array}{l}\overline{\mathbf{z}} \\
\mathbf{\Xi} \\
\end{array}$ & 岕 & 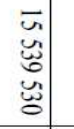 & $\begin{array}{l}\overline{\vec{v}} \\
\vec{\Xi} \\
\vec{\infty}\end{array}$ & 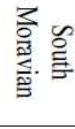 \\
\hline$\dot{\alpha}$ & 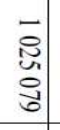 & $\begin{array}{l}8 \\
\mathbf{4} \\
\mathbb{4} \\
+\end{array}$ & 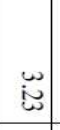 & $\begin{array}{l}\text { Tे } \\
\text { : }\end{array}$ & $\begin{array}{l}\overline{7} \\
\text { : }\end{array}$ & $\begin{array}{l}\overline{\mathrm{O}} \\
\overline{\mathbf{y}} \\
\end{array}$ & 。 & 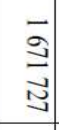 & 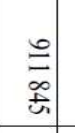 & 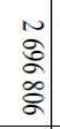 & $\begin{array}{l}\bar{\omega} \\
\bar{s} \\
\vec{s} \\
\vec{s}\end{array}$ & 居 & $\begin{array}{l}\overline{\mathbf{a}} \\
\mathbf{0} \\
\text { 心 }\end{array}$ & 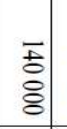 & 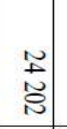 & $\begin{array}{l}\bar{\sigma} \\
0 \\
0 \\
\bar{\sigma} \\
0\end{array}$ & 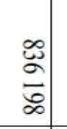 & g. \\
\hline \begin{tabular}{l}
$\infty$ \\
\hdashline \\
\hdashline
\end{tabular} & $\begin{array}{l}\overrightarrow{\breve{b}} \\
\vec{\Xi}\end{array}$ & $\begin{array}{l}\overrightarrow{\widehat{b}} \\
\text { ta }\end{array}$ & $\stackrel{N}{\sigma}$ & : & $\overline{\vec{u}}$ & 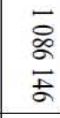 & 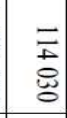 & 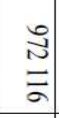 & 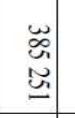 & 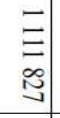 & 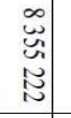 & : & \begin{tabular}{c} 
\pm \\
\multirow{2}{*}{} \\
5
\end{tabular} & 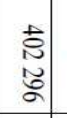 & $\begin{array}{l}\vec{u} \\
\dot{\Delta} \\
\dot{b}\end{array}$ & 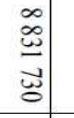 & 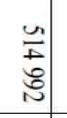 & 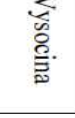 \\
\hline $\begin{array}{l}2 \\
\text { tे }\end{array}$ & 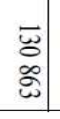 & 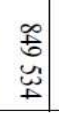 & $\tilde{0}$ & 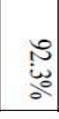 & $\begin{array}{l}\overrightarrow{0} \\
\text { ä } \\
\end{array}$ & 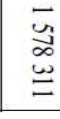 & 10 & $\begin{array}{l}\overline{\breve{s}} \\
\infty \\
\vec{\Xi}\end{array}$ & $\begin{array}{l}\text { के } \\
\infty \\
\infty \\
\infty\end{array}$ & 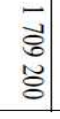 & $\begin{array}{l}\vec{E} \\
\vec{t} \\
\vec{N}\end{array}$ & $\overline{\overrightarrow{0}}$ & 离 & 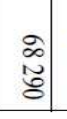 & 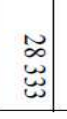 & 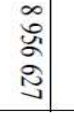 & $\begin{array}{l}\text { 岕 } \\
\text { 怘 } \\
\end{array}$ & 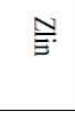 \\
\hline
\end{tabular}

Note: Calculation of individual indicators was accomplished based on algorithm of the Ministry of Finance - see http://www.mfcr.cz/cps/rde/xbcr/mfcr/Priloha_c1_AlgoritmySIMU_2010_xls.xls Source: CSO (2010b); MoF (2010a); calculation made by the author. 